\title{
DISABILITY AND WORK IN THE COAL ECONOMY
}

Thomas Burt's early memories of mining were haunted by the sight of the mutilated bodies of his fellow workers. Remembering his work as a teenage pony putter in the 1850s, responsible for moving coal underground at Murton Colliery, County Durham, Burt recalled that 'everywhere, below ground and above, dangers stood thick'. Compounded by the 'rush and recklessness' of workers there, these dangers meant accidents were common. 'Never', he wrote in his autobiography published posthumously in 1924, 'had I seen so many crutches, so many empty jacket sleeves, so many wooden legs.' Returning to his native Northumberland after his Murton experiences to work at Cramlington Colliery, Burt was again struck by the high frequency of 'accidents to life and limb' and noticed people using 'crutches and wooden legs' among the local population. Although these were 'less conspicuous than at Murton', workers with impairments were a common sight at Cramlington. Burt recorded at least one by name, a mineworker called Bob Barrass who had 'unhappily lost an eye' but worked as a rolley-way man, maintaining the underground roads on which coal was transported. The dangers at Cramlington were so 'great' and the incidence of injury so high that Burt regarded it as remarkable that both he and his father 'were fortunate enough to leave the place unscathed and uninjured'. ${ }^{1}$

Written from the perspective of his later role as an MP and trade unionist, Burt's comments about the high number of injured workers he encountered in mining were intended to highlight the dangers faced by miners in pits where the safety of workers seemed to matter less to colliery owners than profit. Yet, beyond the political and rhetorical use to which he put them, Burt's observations also raise important questions about the supposed consequences of industrialisation for 'disabled' people. As Burt's recollections make clear, workers with impairments were not automatically forced from the mines 
during the Industrial Revolution but continued to work there in considerable numbers despite their injuries. If industrialisation was such a calamity for disabled people's working lives, as some disability scholars have argued, how were so many people with impairments able to work in a sector crucial to Britain's industrial economic development? And how far, if at all, did they, or others, actually regard themselves as 'disabled' people?

This chapter addresses these questions by examining the nature of mine work and the development of mining in the nineteenth century, paying special attention to the factors that enabled injured workers to participate in the working life of collieries and the extent to which they did so. To understand perceptions and experiences of disability during industrialisation it is necessary to examine the nature of 'industrial work' in all its forms. This chapter facilitates such an assessment by specifically exploring the ways in which economic factors, from working techniques and changing technologies to contracts and conditions of employment, affected the perception and experiences of injured and impaired mineworkers. It explores the extent of disablement in coalmining and analyses the working experiences of people with impairments within coal mines and their surrounding communities. In the process, it re-evaluates the relationship between 'disability' and work in industrialising Britain and suggests that popular ideas about the impact of the Industrial Revolution on disabled people's lives that emphasise their exclusion from work need re-thinking. ${ }^{2}$

\section{The nature and conditions of mine work}

Mineworkers' experiences in the coal industry were shaped by the differing economic trajectories and geologies of the specific coalfields in which they worked, as well as the significant cultural differences between them. The most glaring of these, particularly in the early nineteenth century, concerns the division of colliery labour and the employment of women and girls. According to the report of the commission set up to investigate children's employment in mines published in 1842, 'female Children of tender age and young and adult women are allowed to descend into the coal mines and regularly ... perform the same kinds of underground work, as boys and men' at some collieries in Yorkshire and Lancashire. ${ }^{3}$ The practice of female work in south Wales' early nineteenth-century mines was 'not uncommon' either, but was most prevalent in Pembrokeshire, where women worked on the surface and underground usually operating a windlass by which loads of coal were drawn up steep passages. ${ }^{4}$ Female mine work had been declining since the start of the nineteenth century and in some areas, such as north-east England, women were 
already excluded from working underground. ${ }^{5}$ By the time of the Children's Employment Commission only an estimated 4 per cent of all British workers in coalmining were female. ${ }^{6}$ Of these women and girls, however, a substantial proportion (2341, or about 40 per cent of the total) worked at Scottish mines, particularly in the eastern part of the coalfield. ${ }^{7}$ Here, women and girls were heavily involved in underground work and were employed in hauling and bearing coal in significant numbers. ${ }^{8}$ Women's work in early nineteenthcentury Scottish coal mines was a legacy of the system of serfdom in Scottish coalmining, which had lasted from 1606 until 1799, where whole families had been bound to mine owners for life. ${ }^{9}$

The Mines and Collieries Act passed in August 1842 prohibited all females and boys under the age of ten from working underground. ${ }^{10}$ Women continued to work in various capacities above ground at collieries, but their involvement in underground tasks ceased. ${ }^{11}$ Although the numbers of women working at collieries at each census between 1841 and 1911 remained fairly consistent at between 4000 and 6000, the female proportion of the total workforce declined from around 3.5 per cent in 1841 (just before underground work became illegal) to less than 1.25 per cent after $1861 .{ }^{12}$ Moreover, although the law prohibiting boys under ten from working below ground was sometimes flouted, the 1842 Act meant that the age profile of the underground work force became more mature. ${ }^{13}$ While underground mine work had arguably always been seen as a masculine domain - even in Scotland where one female miner reported that 'men about this place don't wish wives to work in mines but the masters seem to encourage it' - the gendering of coalmining as men's work was, after 1842 , reinforced by government regulation. ${ }^{14}$

There were many different jobs at collieries, on the surface as well as below ground. An account of South Hetton Colliery near Durham published in the Penny Magazine in 1835 indicates the diversity of occupations at a single pit. At the top of the hierarchy were the colliery manager, viewer (an agent or surveyor appointed by the owner to run the colliery), first and second engineer and surgeon. Above ground worked thirteen joiners and sawyers, seven engine-wrights who made and repaired the pit's machinery, eight engine-men employed to keep the machinery working, nine firemen to attend the boilers, eighteen smiths to prepare the iron work required in the machinery and wagons, eight masons, six labourers, eleven cartmen, nine horsemen and a saddler. Other employees at the surface included banksmen (who emptied the tubs or corves of coal), boys employed to pick out stones and clean the coals, and railway attendants. Of the colliery's 526 employees, 210 worked above ground; the rest worked below at cutting or hewing coal, hauling it, or as underground foremen and support workers. ${ }^{15}$ 
By the end of the nineteenth century there were more than 200,000 men, women and children working at the pithead. This work, as John Benson has demonstrated, could be heavier, dirtier, more unpleasant and dangerous than many other jobs above ground in Victorian Britain. While rarely considered in eighteenth- and nineteenth-century discussions of occupational morbidity in the coal industry, surface workers faced a number of threats to their health and well-being, such as inhalation of coal dusts, the danger of various accidents such as being run over by wagons, and ruptures and strains from heavy lifting. ${ }^{16}$ The variety of roles available at mines gave rise to an occupational hierarchy within the coal industry that was reflected in different levels of pay and status between jobs. The fundamental division in colliery work was between those who worked above ground and those who worked below. Working below tended to attract higher pay, was regarded as higher status and, as we shall see, carried considerable risk of accident.

Of the numerous non-supervisory jobs below ground, hewing, or coalcutting, was at the top of the occupational hierarchy. It commanded the best wages and had the highest occupational status throughout Britain's coalfields. As former County Durham pitman George Parkinson recalled with great pride, hewing was 'the highest unofficial position attainable' underground. ${ }^{17}$ In Scotland and north-east England, hewers regarded themselves as skilled craftsmen rather than common or unskilled workers and compared themselves to other skilled artisans such as stonemasons. ${ }^{18}$ The status of the hewer was reinforced by the belief that, in Parkinson's words, he had the 'hardest' of mining jobs. ${ }^{19}$ It was hard in two senses. First, it was physically arduous. As the Colliery Guardian observed,

The hewer sits on a low stool (four inches in height) and grasping his pick with both hands, makes successive horizontal blows. To give the greatest effect to the stroke, his head is thrown back to one side, his left leg extended and his right bent, his right elbow resting on the right thigh, enables the leg to augment the force of the arm..$^{20}$

Physical exertion was common to all hewing, but the degree of physical toil was affected by local geological conditions. The differing softness or thickness of the seam was also important in determining the physical demands on the bodies of miners. 'The differences of thickness sometimes admit the erect posture,' noted the Penny Magazine, but often men were obliged to 'sit, recline, or bend the body to an extreme degree.' The exploitation of deeper seams increased the temperature in which hewers worked, a situation exacerbated by having to work in very narrow, confined spaces in some collieries. ${ }^{21}$ As we shall see in the following chapter, the health of coalminers was frequently judged by 
their posture and the deleterious effects of working in contorted positions for long periods of time.

Second, coal-cutting not only necessitated physical strength and endurance, it also entailed technical skill on the part of the hewer and 'considerable dexterity and experience'. ${ }^{22}$ Generally, large coals fetched a better price at market and were the most prized, both by colliers and mine owners. To get these, miners had to work the coalface with great care, so as not to break slabs of coal into less valuable small coals. ${ }^{23}$ Being a successful hewer depended on the ability to use a variety of tools and interpret the geological and other conditions in which a miner worked. ${ }^{24}$ Hewing may have been physically strenuous, but it was not just a matter of brute force that simply favoured the most able-bodied above all others. It was from a combination of the strength and skill required by their job that hewers derived their strong occupational identity and pride. ${ }^{25}$

Nevertheless, the earnings of mineworkers depended on their capacity for hard physical toil. Colliers throughout Britain's coalfields were generally paid at piecework rates, which based pay on the amount they produced rather than the hours they worked. In north-east England, where miners were primarily employed to cut coal and nothing else, the relationship between coal produced and earnings was fairly simple. In south Wales, the terms under which colliers worked meant their earning potential was not so straightforward. While they too were paid for how much coal they produced, they also received remuneration for much of the non-cutting support work they performed. Colliers in south Wales were responsible for propping and maintaining the area around their individual workplaces, whereas in north-east England hewers usually left this to ancillary workers. In addition to this, Welsh colliers loaded their produce into coal trams for transportation to the surface. ${ }^{26}$ The pay for these tasks tended to be determined on a piece rate basis as well. The problem with this was that ancillary work usually paid much less than coal-cutting. Consequently, Welsh colliers were under financial temptation to minimise the time they spent on 'offhand' or 'deadwork' (such as propping) and concentrate their efforts on hewing, which was better rewarded. Although less profitable, however, ancillary work was vital to safety. Without adequate propping, for instance, underground work spaces were more susceptible to roof falls. It is possible, therefore, that the organisation of work in the south Wales coal industry, combined with its remuneration practices, operated in a way that increased the risks to which Welsh miners were exposed and contributed to its notoriety as a particularly dangerous coalfield. ${ }^{27}$

Hewers made up a significant proportion of the underground work force at British collieries in the nineteenth century. Benson estimates that around half 
of those employed below ground were involved in cutting coal. ${ }^{28}$ The other half worked in support roles. Ancillary tasks included hauling and bearing coal, and trapping, or operating the underground doors important for mine ventilation. Although mines required some skilled support workers, such as those who maintained the tracked roadways on which coal trucks were transported, much underground support work was heavy and unskilled in nature. ${ }^{29}$ Both before and after the Mines and Collieries Act of 1842, hauling and trapping tended to be undertaken by the youngest sections of the underground workforce, although after the 1842 Act haulage work was increasingly done (where passages were wide enough) by pit ponies rather than human bearers. In north-east England, the hierarchy of underground work mapped onto the age of workers. As a witness to the Parliamentary Select Committee on Accidents in Coal Mines of 1835 explained, the youngest workers began as trap door keepers (12-14 years), stronger boys moved on to work as rolley drivers (responsible for moving wheeled sledges of coal known locally as 'rolleys'), before moving on to putting (hauling coal through underground passageways by any means). ${ }^{30}$ The transition from putter to hewer was an important stage in a miner's life cycle, marking the transition from youth to adulthood. When he began hewing at Seaton Delavel Colliery from the age of eighteen, Thomas Burt remarked that he 'now ceased to be a boy and henceforth was a man'. ${ }^{31}$

In south Wales, the progression to coal-cutting and the distinction between face and 'offhand' work was less clear. Despite this, there was still some correlation between age and position. Young Welsh mineworkers served a more traditional form of apprenticeship than their counterparts in north-east England, learning their trade alongside a more experienced collier as his 'lad'. Although he may have performed some hewing as well as support tasks, a collier's lad generally spent more time engaged in ancillary work than cutting. It was not until their early twenties that Welsh 'lads' usually became full colliers in their own right. ${ }^{32}$ The south Wales miner Edmund Stonelake, who started working underground in the 1880s, described how, in the absence of his deceased father, his mother had searched for a collier with whom he could be placed who could 'look after my safety, discipline me, and shelter me from bad company'. After initially being placed with an 'illiterate drunken Cornishman', he was transferred to a 'proper gentleman collier, a tall smart elderly man who kept himself aloof from other colliers, in the work and out of it'. ${ }^{33}$ Although the ages at which youths became hewers varied, adult men normally undertook the hard, skilled and prestigious work of coal-cutting.

Just as there was much diversity in the type, nature and difficulty of jobs available at collieries, so too was there great diversity in the terms of employment governing mineworkers. Pay and contracts differed widely not only from 
coalfield to coalfield, but also within them. Miners had a deserved reputation as well-paid workers. Commenting on their situation in 1798, Thomas Gisborne noted that an average miner was consistently able to earn more than an agricultural labourer. ${ }^{34}$ Hewers were the best paid of mineworkers, but throughout the period all underground workers were relatively well paid compared to other manual workers in agriculture, building and railways as well as non-agricultural labourers. ${ }^{35}$ This was due to the greater risk of death or disablement involved in underground work and, to an extent, the related difficulties some employers faced in attracting people to work there. ${ }^{36}$ In the first part of the nineteenth century, political economists argued that wages ought to reflect and compensate for any dangers that employees might face in the workplace. ${ }^{37}$ Coal owners were especially keen to make a connection between the risks of mining and the relatively high wages they paid to their workers and, as we shall see in subsequent chapters, often supplemented these with paternalist benefits such as workplace medical schemes. ${ }^{38}$

Nevertheless, in spite of the theoretical link between rates of pay and exposure to the threat of death or disablement, the structure of miners' earnings was shaped by a variety of factors that went beyond the question of risk itself. All mineworkers were potentially subject to varying economic fortunes due to the vagaries of the market, whereas the temporary closure of pits due to flooding or explosions, could put many out of work. Individual earnings (as opposed to wages) varied by the number of shifts someone was able to undertake. ${ }^{39}$ Hewers' earnings were determined by the geological structure of seams and local custom. Those working at cutting coal in north-east England tended to be paid better than those doing the same work elsewhere. ${ }^{40}$ Moreover, there were differences within regions as well as between them. Miners working at collieries attached to iron works generally received less pay than their counterparts working in the sale coal sector, but were generally less susceptible to the vicissitudes of market fluctuations thanks to the more constant demands of the blast furnaces. ${ }^{41}$

Pay was not the only term of employment for mineworkers that varied widely from place to place. There was much diversity in the nature of contracts generally. Their length, for instance, could range from one month or less to several years. The three coalfields had quite different traditions in this area. Until the abolition of the bond system in 1872, mineworkers in north-east England entered into a legally binding agreement with their employers, usually on an annual basis, though there were some years when monthly bonds were used instead, particularly after the unsuccessful miners' strike of 1844. In principle, this system of hiring gave pitmen some security of employment, providing they kept to the terms of their bond, which were often onerous. For 
example, workers faced imprisonment if they left their pits without permission, even if they perceived their lives to be in imminent danger. ${ }^{42}$ The bond also empowered mine owners to enforce strict discipline of attendance and extend surveillance over workers during sickness. In their 1825 list of grievances, $A$ Voice from the Coalmines, Tyne and Wear pitmen complained that they were fined $2 \mathrm{~s} 6 \mathrm{~d}$ for absence 'unless we produce a certificate from the surgeon certifying we are ill'. ${ }^{43}$ In south Wales, colliers in the mid-nineteenth century were usually employed on monthly contracts. ${ }^{44}$ At the other end of the spectrum were some mineworkers in Scotland. In Midlothian, nineteenth-century miners were bound to coal owners under similar terms to miners in north-east England, sometimes for durations of anything up to five years. Long as this was in relation to the contracts governing mineworkers in other parts of Britain, this was a short time compared to the lifetime bondage and virtual serfdom experienced by colliers in Scotland in previous centuries. The trend over the nineteenth century in the coal industry, however, was generally towards shorter-term contracts more likely to last months or weeks than years. ${ }^{45}$

The massive and rapid expansion of mining in the nineteenth century therefore increased the demand for mine labour and opened up many new opportunities that mineworkers were keen to exploit. Nevertheless, it also presented dangers of death and disablement that coloured public perceptions of coalmining and miners' own views of their occupation. The remaining sections of this chapter explore how economic expansion increased the risk of accidents and how the nature and conditions of mine work outlined so far shaped the experiences of miners with injuries and impairments and influenced their ability to return to work.

\section{Accidents and disability in the mining industry}

Fatal mining disasters exercised a powerful grip on the public imagination in nineteenth-century Britain and have dominated discussions of health and safety in historical studies of coalmining. ${ }^{46}$ In the period $1835-1880$, fourteen major disasters each claiming more than 100 lives occurred at British collieries. The deadliest incident among miners of south Wales, Scotland and north-east England at this time was the explosion that killed 207 people at Blantyre Colliery in Lanarkshire in October 1877 - the worst disaster in Scottish mining history. ${ }^{47}$ In 1850 the risk of mortality by occupational accident was around four or five times higher for mineworkers (4.5 to 5.0 per 1000 employed per year) than for the rest of the working population. ${ }^{48}$ Deadly explosions, in particular, were widely reported in the press and were a focal point for public concerns about safety in the workplace. They 
prompted investigations into mine safety by engineers, stimulated collective action by workers around the questions of risk and compensation for victims and their families and, ultimately, acted as a spur to increasing government regulation. ${ }^{49}$

Despite the preoccupation with fatalities, death was not the only outcome of mining accidents. ${ }^{50}$ However, due to poor record keeping, the exact scale of non-fatal accidents is difficult to measure. Although the first public investigation into mining accidents conducted in 1835 had called for the future collection of accident statistics, this recommendation was not supported by legislation, and casualty reporting remained patchy and incomplete until much later in the century. ${ }^{51}$ Nevertheless, the impression that emerges from the available sources suggests that non-fatal accidents were more common than fatal ones. In the early 1840s, for example, it was estimated that the ratio of accidents in south Wales with 'disabling' consequences to numbers employed was 1 to 500, compared to a ratio of fatal accidents to numbers employed of 1 to $1000 .^{52}$ In his report on the mines of the south Durham coalfield, Dr James Mitchell gathered data from three unnamed collieries detailing the 'time, place and mode of maiming' experienced by workers and the amount of time they had lost through sickness. Injuries included bruising, lacerations and fractures, and the more general description of being 'lamed', which could indicate both temporary and permanent impairment. ${ }^{53}$ For the most part, though, mine owners and colliery doctors were unable - or unwilling - to provide information about injuries. Charles Forrest, surgeon of Hirwaun Iron Works, regretted that he could not furnish statistics 'touching the number of accidents and proportion of able-bodied men as compared with the disabled' since he had 'never kept a record of all the accidents occurring in the works, merely making notes of remarkable cases professionally'. ${ }^{54}$ John Roby Leifchild remarked in his report on Northumberland and North Durham that 'accidents terminating short of death are seldom heard of beyond the place of their occurrence'. ${ }^{55}$ In general, then, official reports during most of the nineteenth century probably underestimated the number of non-fatal accidents. ${ }^{56}$

The reporting of non-fatal accidents did improve, however, as the century progressed, due to the increasing involvement of legislators in the regulation of industry. The Mines Act of 1850, for example, introduced a system of official inspection in the hope of reducing fatalities from explosions, and from 1855 mine owners and their agents had a legal responsibility to report 'any serious personal Injury' to inspectors. ${ }^{57}$ While at first this was interpreted as referring primarily to injury by explosion, by the time of the 1872 Mines Act, the requirement had been extended to the reporting of serious injury 'by any accident whatever'. Failure to report serious accidents, moreover, became a 
punishable offence, with fines levied potentially going to workers who had been hurt in mining. ${ }^{58}$

Reporting of 'serious injury', however, was highly variable. As J. B. Atkinson, the inspector for South Durham noted in his report for 1863, 'a considerable amount of doubt, as well as difference of opinion, appears to prevail amongst the agents of the collieries of the district as to the amount of personal injury which constitutes what the Inspection Act terms serious personal injury. ${ }^{59}$ Reporting 221 non-fatal accidents in 1862 and 239 in 1863, the inspector for west Scotland's mines cautioned that 'it would be fallacious to accept these [figures] as a correct and full return of accidents which happen in mines,' since the term 'serious personal injury' is 'difficult to determine'. ${ }^{60}$ Although this may have led to the underreporting of non-fatal accidents, in some cases mine owners were anxious to report any incident to make sure they stayed on the right side of the law. This was particularly true after 1872, when the law left no 'doubt' about mines' legal responsibility to 'notify' the authorities about all 'death arising from slight injuries'. ${ }^{61}$

The lack of comprehensive health and safety statistics for our period makes it hard to discern the relationship between industrial change and the incidence of impairment with any great precision. ${ }^{62}$ For many eighteenthand nineteenth-century Britons, however, a link between the expansion of the coal industry and a presumed increase in the occupational risks facing miners seemed clear. While the comparatively small size of pits in the early modern period had tended to keep accidents and fatalities to relatively low levels, the increasing scale and depth of mines from the late eighteenth century onwards, along with the rapid growth in the number of workers employed in the sector, began to raise concerns about the safety of coal pits. ${ }^{63}$ These fears were fed by growing and sensational reports of accidents in and around coal mines. In the late eighteenth century, such reporting was a regular, if infrequent, feature of press coverage of 'casualties'. For example, in 1788 the Whitehall Evening Post reported an accident at Stratton in Somerset, when two mineworkers were killed and 'six more burnt in a terrible manner' after the 'damps of the pit took fire'. ${ }^{64}$ As demand for coal increased and mines were driven deeper, more 'gassy' and dangerous seams were worked, increasing the risk of explosions. By 1813, worries about the number of underground explosions in north-east England led to calls there for the establishment of the Society for the Prevention of Accidents in Coal Mines, motivated by the 'humane purpose' of saving the lives of those involved in an industry that 'contribute $[\mathrm{s}]$ so essentially to our comforts'. ${ }^{65}$ In the opinion of colliery viewer John Buddle, giving evidence to the House of Lords in 1829, it was those collieries in north-east England 'producing the best coals' that were 
most liable to explosions that caused loss of life or left an 'immense number of cripples' ${ }^{66}$ With increasing profits available as demand for coal rose, moreover, miners were exposed to new risks alongside the threat of explosions. For example, the practice of 'robbing' supporting pillars of as much coal as possible to maximise output not only required miners to work in extremely gassy parts of mines, it also meant they were at greater risk of roof falls. In addition to these more dramatic risks, deeper and more intensive mining also meant miners had to work in hotter and more stuffy environments, to the further detriment of their health. ${ }^{67}$

Deep mining necessitated innovations in ventilation, drainage, winding gear, lighting and transportation. ${ }^{68}$ Ventilation, in particular, became a critical concern, as public worries about the increasing frequency of explosions mounted. New methods of ensuring the flow of air through underground passages were developed. These included the use of furnaces at the pit bottom to draw air through the upcast shaft. By 1830, such ventilation techniques were commonly employed at British collieries. Further efforts to improve ventilation were made from the 1840 s onwards, when exploitation of the explosion-prone steam-coal seams of south Wales intensified. Experiments with air pumps and mechanical fans, for instance, were conducted. ${ }^{69}$ Together with the system of government inspection, these developments probably made mines safer. Fatalities from explosions fell during the second half of the nineteenth century and former hewer Thomas Burt certainly believed that health and safety at British mines had improved alongside industrial expansion in the nineteenth century. Born in 1837, Burt came from a long line of miners. 'My paternal grandfather, who died before I was born,' recalled Burt in his autobiography, experienced debilitating respiratory problems brought on by a life in mining. In Burt's view, his grandfather's 'early death was not improbably due to the bad underground ventilation of those days' ${ }^{70}$ However, the exposure to risk and injury varied between and within mining districts. Such differences stemmed from the different geological conditions and extraction methods in the coalfields, as well as the uneven pace of economic development in the industry. ${ }^{71}$

Although technological and regulatory developments had beneficial effects, they did not eradicate the considerable risks faced by colliery workers. Sometimes, in fact, technological advancements actually posed new dangers for the workforce. ${ }^{72}$ In the eighteenth century, water-powered machinery was often used at collieries for winding and pumping and was regarded as an improvement on human or animal powered technologies. ${ }^{73}$ Yet such machinery could prove hazardous to use. In June 1787, the Public Advertiser reported that one man was fatally mangled when his clothes became caught in a chain 
attached to a colliery waterwheel near Oswestry. In attempting to save the poor man, another person's hand was also severely 'crushed' in the incident. ${ }^{74}$

The introduction of the miner's safety lamp (popularly known as the Davy lamp after its inventor, Humphrey Davy) around 1815 reduced the risk of explosion from naked flames, doubtless saving lives, but its use was controversial and varied between coalfields. Safety lamps gave off poor light, which made some miners abandon them, sometimes with tragic results. In $A$ Voice from the Coal Mines (1825), colliers from Tyne and Wear complained that safety lamps were a great advantage to coal owners 'but a great injury to the comfort and earnings of the pitmen'. Coal owners fined workers for any deficiency in separating inferior coal from the superior, but this proved difficult in the dim light provided by the Davy lamp. Furthermore, they argued, the Davy lamp was an 'accessary to the destruction of our health; bringing on rapid old age and general imbecility', wrecking the eyesight of miners and encouraging mine owners to take risks in forcing their workers to mine more dangerous places. ${ }^{75}$

Unionised miners may have overstated the nature of the risks they faced to convince the public of the justness of their industrial disputes with owners. Yet others broadly agreed with them, including arguably the most famous mining expert of the time, John Buddle. Four years after publication of $A$ Voice from the Coal Mines, Buddle echoed the claims of pitmen when he gave his opinion on the effects of the Davy lamp on mining safety in north-east England to Parliament. While Buddle accepted that safety lamps had probably reduced the number of explosions, he did not believe this had radically improved mine safety. The adoption of this new technology, in his view, had merely changed the risks to which miners were exposed. Comparing fatality statistics before and after the introduction of Davy lamps, Buddle reckoned 'the loss of life has been ... about the same'. The reason for this was that 'we are [now] working mines, from having the advantage of the safety lamp, which we could not have possibly worked without it, and of course they are in a more dangerous situation, and the risk is increased in a very great degree. ${ }^{76}$

No matter what safety regulations or technological improvements were introduced at mines, however, it was impossible to eradicate the folly of individual workers. The 'rush and recklessness' that Thomas Burt witnessed at Murton Colliery was believed by many to be endemic among nineteenthcentury mineworkers, and such claims were sometimes used to undermine pitmen's claims to occupational status. ${ }^{77}$ The opinion was reinforced in the press and in the reports of government officials. In Scotland in 1863 it was reported that many 'inexperienced and rash men' were the cause of underground accidents. ${ }^{78}$ In 'A Coal Miner's Evidence', which purported to be a first-hand account of an explosion from a Durham miner published in Household Words, 
it was claimed that many mining deaths were caused by the 'carelessness and folly' of miners: 'It's just in our nature not to care - that's all. ${ }^{\text {'9 }}$

Perhaps some miners were just 'careless' by nature, but the class prejudice apparent in many reports about the 'reckless' behaviour of industrial workers ought to be recognised too. Hewers took risks with their health and safety not simply because they were foolish, but because they sought to maximise their earnings in an incredibly dangerous industry. As noted earlier, the payment of hewers by piece rate may have encouraged some to take extra risks with their lives and health for the sake of an increased pay packet. Seen in this light, then, colliers appear more as rational, if sometimes fallible, actors taking calculated risks than unthinking fools. ${ }^{80}$

While explosions were the focus of much discussion of safety in mines, inspectors' reports highlight other dangers, particularly roof falls and accidents relating to the transport of coal, as the primary causes of non-fatal injuries. ${ }^{81}$ For instance, Lionel Brough, whose inspection district covered the south-west of England and part of south Wales, reported seventy-five non-fatal accidents involving ninety-one persons in 1863, in which there were twice as many accidents caused by falls of coal and stone (thirty) than those caused by explosion of 'fire damp' (fifteen). Thirty-four men and boys suffered fractures, burns and other injuries from accidents in shafts or 'by miscellaneous causes' ${ }^{82}$ Brough's report for the year 1869 listed 125 persons injured in 111 accidents, of which the largest number ( sixty) were 'wounded, contused, or suffered from fracture of bone, or underwent amputation' from falls of coal or stone. ${ }^{83}$ The report for the west of Scotland similarly listed falls of rock or coal as the primary cause of non-fatal injury, accounting for ninety-nine casualties. ${ }^{84}$ In the report for north-east England that year, twenty-four workers were injured by falls of stone or coal, while eleven were 'run over or crushed by tubs' ${ }^{85}$

The bodily risks mineworkers were exposed to varied according to the kind of tasks they were expected to perform. Consequently, the perils of mining did not affect all colliery workers equally. Putters or trappers, for instance, were more likely to be injured in accidents involving coal tubs than hewers. Given that a mineworker's position in the underground workforce was often directly related to his age, moreover, it seems age and experience were important determinants of risk. As Jamie Bronstein has observed, nineteenth-century fatality figures suggest that young and inexperienced mineworkers were more likely to be killed or injured at work than older, more experienced, colleagues. ${ }^{86}$

In general, the 'serious injuries' reported by the mines inspectors did not make clear distinctions between those which threatened a worker's livelihood through permanent disablement and those from which recovery was possible, nor did they take account of other long-term health problems such 
as respiration difficulties caused by inhaling dust or physical problems caused by working in damp, cramped environments. Though inspector Herbert Mackworth estimated in his report for south Wales and south-west England for 1855 that about twice as many were 'disabled for life' by mine accidents than were killed, inspectors noted that many victims of 'serious injury' were 'restored to usefulness' ${ }^{87}$ Of the seventy-five accidents reported to Hedley in 1862 that injured eighty persons, 'only one of these ... has resulted in a permanent deformity' - a man who was seriously hurt by leaning out of the cage as he descended the mine shaft, which resulted in facial disfigurement and the loss of sight in one eye. ${ }^{88}$ It is unclear whether this man's 'permanent deformity' equated to an inability to work. The nature of the injuries sustained in accidents and their effects on individuals varied considerably. For example, among the victims of falls of rock or coal listed in the East Scotland Mines Inspection Report for 1880 were a twenty-six-year-old collier whose leg was injured resulting in just seven days off work and an eighteen-year-old 'brusher' whose arm and leg were broken, leading to a lay off of 120 days. A drawer from the Arniston Coal Company's mine aged fourteen whose legs were 'injured by chain on a wheel brae' had been unable to work for eight months and was 'still off' ${ }^{89}$ The final section of this chapter examines the experiences of injured or impaired miners in more detail to reassess the relationship between 'disability' and the industrial workplace.

\section{Disability and work}

Many factors influenced the perceptions and experiences of mineworkers with impairments. The nature of their bodily capacities was undoubtedly significant in this regard, but so too were the conditions and organisation of work set out earlier on in this chapter. These influenced the 'somatic flexibility' available in the industrial workplace and affected the ability of workers with impairments to participate in the labour force. The attitudes of employers and fellow workers were also important, as these could determine whether impaired mineworkers were actually welcome at mines or not.

In the eighteenth and nineteenth centuries it was common to define disability in relation to work, but impairment was a matter of degree and did not necessarily equate to an inability to do any work at all - something that, as we will see, welfare officials at the time were often keen to stress. ${ }^{90}$ In line with other workers, mineworkers could potentially experience two kinds of disability: occupational and general disability. ${ }^{91}$ As the term implies, occupational disability meant that a person was unable to pursue their normal employment due to ill health or injury. Referring to the Scottish town of Tranent in 1840, 
which had a high number of infirm, ill and injured colliers among its population, sanitary inspector S. Scott Alison relied on an occupational definition of disability when he wrote:

A great number of persons in and around Tranent are unfit to follow their usual occupation on account of bodily injuries by accidents, and of disease caused by their occupation..$^{92}$

While this meant that people were disabled from doing their usual work it did not mean that they were entirely incapable of labour. General disability, in contrast, meant a person was totally incapacitated for any kind of work. This definition of disability was perhaps the most dominant at the time. As Martha Stoddard Holmes contends, the idea that disabled people were incapable of work was an incredibly popular one in Victorian literature and popular culture. ${ }^{93}$ Despite such popular representations, however, the relationship between 'disability' and inability to 'work' was rarely straightforward in practice.

The history of Britain's coalfields provides compelling evidence of this complexity. It was not inevitable that illness and injury forced mineworkers from colliery labour forces. As is clear from the description of men with crutches and wooden legs encountered by Thomas Burt working in the mines of mid-Victorian Durham that began this chapter, people with quite significant impairments were not excluded from underground work. Indeed, the 1842 Children's Employment Commission had returned evidence of many people with 'disabilities' working in Britain's coal mines. Among those working at Birsley Colliery near Tranent were William M'Neil, an eleven-year-old boy, 'deaf and dumb, who had wrought below two years'. At Polkemmet Colliery in Linlithgowshire (West Lothian) worked another eleven-year-old, Catherine Thomson, who had returned to work after having her knee crushed by a cart, which continued to cause her great pain and she could 'scarcely stand' after pushing carts all day. Another child worker, Taylor Coats, who hooked and unhooked chains off rolleys at Percy Main Colliery in Northumberland, had been 'lamed twice' by his work, resulting in absences of three weeks and twenty-two weeks respectively. Now he 'walks lame. Has a bad step; cannot walk comfortably' but continued his work at the pit. ${ }^{94}$ Undoubtedly, the evidence of impaired children working in the mines served to highlight the horrors of the industry, just as reformers had used accounts of young 'factory cripples' in the previous decade to campaign for regulation of the manufacturing industries. ${ }^{95}$ Nevertheless, these accounts served to reinforce the view that injury, impairment and living with pain or other difficulties was part of the experience of work in the coal industry. 'Working through' sickness or 
impairment was part of nineteenth-century British working-class experience and was not simply a rhetorical image used by reformers to garner support for their cause. 96 'Disabled' Britons worked throughout the nineteenth century, often in some of the most physically arduous industries of the time.

The most vivid first-hand account of the working life of an impaired miner is that left by trade unionist Edward Rymer. Born in Boldon near Sunderland in 1835, Rymer was seriously hurt in a house fire as a young child, which left him significantly visually impaired and 'permanently injured' on the right side of his body. His defective eye-sight had, he wrote, a 'sad and serious effect on my whole life', and he referred to himself as a 'cripple'. Nevertheless, he was employed in a variety of jobs underground in pits in the north-east and other parts of the country, beginning work like many young people did as a trapper, moving on to hauling tubs of coal as a putter and eventually, in 1860, to hewing coal. At each stage of his career, Rymer wrote of the ways in which his impairments, and the attitudes of others to them, affected his experience of work. If his 'defective sight' did not act as a barrier to mine work, he wrote frequently of how it made his work more onerous, or caused others to exploit him. It caused him 'endless troubles' as a young trapper, leading those of his fellow miners who were 'disposed to act the part of tyrant or persecutor' to impose extra tasks upon him. He felt isolated through his impairment, describing himself as a 'lad half blind and friendless' and, when working as a horse-driver, wrote that 'my failing sight frequently led me to make mistakes'. It was at this point, he wrote, that his 'partial blindness ... dawned on me with full force, and brought out all the cunning in my nature, since I had to watch every point, crossing, and turn in the workings'. The physical exertion also took a toll on his limbs, as did working in damp parts of the mine, which brought on rheumatism. Fearing physical 'ruination' when he was assigned to a haulage job after having worked for a time as a hewer, Rymer asked to return to coal-cutting, but was refused. His preference for hewing was so strong that he broke his bond and absconded - an offence for which he was later imprisoned. Rymer's wish to work as a hewer was probably affected by the better pay and status it attracted, but he also seems to have thought that hewing offered less severe challenges to his body than hauling coal through dark passages. ${ }^{97}$

While the high status and better pay associated with coal-cutting may have made it the job of choice for many mineworkers, not all colliers were able to resume their occupation after injury. Some miners were so badly injured that they were unable to muster the strength or bodily dexterity necessary to make a living as hewers. This did not always stop them working at lighter jobs however. As we have seen, the coal industry was occupationally diverse. In 1829, John Buddle explained that in north-east England men made 'cripples' 
in mine accidents needed to be 'provided with some employment which they could manage'. Consequently, 'many of them go to boys' work, what is called trapping, furnace keeping, and a great many jobs that might be done by boys, if it was not for the sake of employing these cripples and disabled persons' ${ }^{98}$ Some impaired miners took up surface work. Evidence given by William Morrow, a fourteen-year-old employee of Tyne Main Colliery, to the 1842 Children's Employment Commission provides a vivid example of how an individual's working life might change with injury. William had begun work underground at a different pit as a trapper, but had fallen asleep one night by his door and some wagons ran over him, shattering his leg. The leg was amputated and he was fitted with a prosthetic limb, but he was able to return to his door keeping work. Nevertheless a series of accidents, including having his head cut by a fall of rock, breaking his arm and cutting his brow when coal fell from a wagon, had led to him taking work on the surface, where he kept the 'foot of the inclined bank'. ${ }^{99}$ Old and infirm colliers often worked aboveground as 'callers' or 'knockers' who roused mining households to ensure workers were up in time for their shifts. ${ }^{100}$ Others became 'lampmen' and were responsible for checking, maintaining and storing safety lamps. ${ }^{101}$ Injured mineworkers were not automatically cast off and excluded from colliery work. Many were able to continue working in the coal industry, both above ground and below. ${ }^{102}$ Some resumed their pre-injury occupations while others took up new, less arduous positions.

The status of miners with disabilities varied considerably and might depend on a person's standing prior to their injury and the work culture of particular collieries. Those like Rymer whose impairments were acquired prior to working in the mines sometimes faced the scorn or suspicion of co-workers. Rymer frequently complained of his physical defects being used against him, such as in a dispute with an overman over a fair price for putters' labour in which his opponent 'made some brutal remarks' about his 'lameness'. ${ }^{103}$ The assignment of hewers to 'boys' work' might have enabled them to return to work after serious injury, but in an industry where there was a strict occupational hierarchy based on age, such tasks might be deemed demeaning as they would almost certainly carry a loss of earnings and status.

In contrast, as Edward Slavishak has shown, a certain degree of bodily marking or minor impairment might confer status on workers in nineteenthcentury heavy industry as signs of experience or bravery. ${ }^{104}$ In an industry where some degree of 'seasoning' of workers' bodies was expected as part of the process of training and preparation for the arduous nature of pit life, a miner's bodily characteristics instantly placed him in the hierarchy of age and experience that characterised underground work. ${ }^{105}$ The backs of putters, for 
instance, were often scarred as a result of their work. Peter Rutter, a fifteenyear-old youth who worked at Gosforth Colliery in the 1840s, explained that pushing heavy corves of coal through narrow passages meant 'the skin of his back is often knocked off'. At Monkwearmouth, an exceptionally hot mine, workers commonly experienced painful boils when they first went underground, but these tended to disappear over time. Consequently, 'the occurrence of these [boils] is so distinctive a mark of a fresh man, that [an observer] is well aware of the man being unaccustomed to the pit from this occurrence'. ${ }^{106}$ Indeed, Victorian expert on occupational health J. T. Arlidge described certain 'deformities' associated with particular industries as 'trademarks', which acted as badges of occupational identity. ${ }^{107}$

Loss of status or emasculation in the workplace as a result of injury, then, was possible but not inevitable. ${ }^{108}$ Although some men may have been disabled from returning to their former employment, their knowledge and experience might have made them suitable for supervisory roles. Thomas Haswell, killed in an underground explosion at Thornley Colliery near Sunderland in 1841, was an experienced coal hewer, but had been working as an overman, supervising the preparation of the mine between shifts, after breaking both legs in a rock fall the year before. Though newspaper reports of the disaster described him as a 'cripple', Haswell's impairments may have marked him out as a survivor and a man with hard-won experience of mining, earning the respect of the young crew who worked for him. ${ }^{109}$ Colliery overmen might be paid up to $£ 100$ a year in Haswell's day and were generally promoted from the workforce on account of their 'activity, steadiness, natural abilities and education'. ${ }^{110}$ Even when completely incapacitated for work, experienced mineworkers could still occasionally play an active role in the working life of a colliery. Reese Price, for example, was also an overman, at Gethin Colliery in south Wales. While off work following an accident in December 1865, Price was visited by his replacement and asked for advice about a build-up of gas in the mine. Although 'unable to follow' his usual employment, then, Price remained influential. ${ }^{11}$ His knowledge and experience of mining meant he was not pushed aside and forgotten. As we will see in Chapter 5, experience of working in mines was a marketable commodity that may have helped some injured mineworkers find work in the coal industry, particularly at times when experienced mining labour was in short supply, such as during strikes.

Former mineworkers disabled from working underground often found employment in other sectors of the coalfield economy too. For example, a 'disabled man' might occasionally 'take to dealing in small wares' in pit villages, according to one mid-century investigation into life in the mining districts of north-east England, 'and in some cases superannuated hewers will, in addition 
to what light jobs they can pick up about the pit, occupy themselves in collecting the clay used for the workmen's candles'. ${ }^{112}$ Sometimes men disabled from working in the coal mines turned to teaching. During a parliamentary debate on education in Wales in 1846, it was revealed that eleven of Merthyr Tydfil's schoolmasters had been 'miners, or labourers disabled by accidents or bad health'. ${ }^{113}$ Similarly, Leifchild wrote that in the pit villages of north-east England many teachers were 'disabled workmen'. The practice of appointing such men was, in Leifchild's view, evidence of sentiment and a sense of entitlement based on physical sacrifice triumphing over reason since few had 'received an education qualifying them to be successful teachers of the young'. The disabled miner claimed 'from the mutilation or absence of a limb, to be the recipient of the bounty of the benevolent':

It is not seldom that a disabled pitman proposes himself as a candidate for a schoolmastership; and should a vacancy occur in the colliery where his misfortune happened, he deems himself, and is deemed by others, indisputably entitled to the suffrages of all parties. This evinces sensibility to the claims of misfortune, and insensibility to the claims of education. ${ }^{114}$

While for critics such as Leifchild the entry of disabled miners into village schools was evidence of the poor educational provision in mining communities, the belief that injured miners had a moral claim to a job that carried authority and status is interesting and provides further evidence that those disabled from mine work were not necessarily marginalised in this period. Although opportunities for disabled miners may have declined at times of economic hardship, such as during periods of unemployment caused by the temporary or permanent closure of a mine, the occupational make-up of coalfield settlements was sufficiently diverse to offer some disabled colliers viable alternatives to mine work. ${ }^{115}$

The nature of their impairments was not the only factor affecting the ability of colliers to return to pit work after injury. The organisation and nature of mine work itself at this time facilitated the inclusion of 'disabled' miners in the mining workforce by permitting a degree of 'somatic flexibility' supposedly characteristic of the more 'inclusive' pre-industrial economy. ${ }^{116}$ That it did, suggests that pre-industrial approaches to work were not obliterated in the nineteenth century but persisted in industrial settings too. During the late eighteenth and nineteenth centuries, coalmining developed in ways that resisted the conventional models of 'industrialisation' emphasised in accounts of the rise of disabling capitalism. ${ }^{117}$ For example, coal-cutting throughout this period was a matter of individual hand labour that made it difficult to supervise workers closely and led to a degree of elasticity in working arrangements. ${ }^{118}$ 
In the first place, the continuance of piecework, particularly for hewers, gave mineworkers some leeway to decide their pace of work. ${ }^{119}$ Such flexibility may have allowed miners to tailor their working practices and rhythms to minimise the restrictive effects of impairment - even if those unable to win as much coal as stronger hewers faced the prospect of lower pay. George Parkinson, for example, who worked in the mines of mid-nineteenth-century Durham, described one hewer called 'Old Joe' who was 'not physically strong, his earnings were small and his means were scanty'. ${ }^{120}$ The independence of colliers at work was further promoted by the 'bord and pillar' method of extracting coal. This method of mining (also known as 'pillar and stall' or 'stoop and room' mining) consisted of driving a number of passages running parallel to each other from which coal was taken, leaving pillars of rock to support the roof. Although particularly suited to mines where seams were thick and roofs were typically poor - such as those found in Durham, parts of Scotland and the Swansea area of south Wales - bord-and-pillar working was the dominant method for much of the eighteenth and most of the nineteenth centuries. ${ }^{121}$ As the idealised picture of a coal mine in Figure 2 suggests, colliers employed at pits using this kind of system, or variants of it, worked in individual bords or stalls that were separated from those of their colleagues. Working these areas in small groups, colliers were hard for pit managers to supervise. Coupled with the fact that poor lighting and the sprawling scale of many mines made supervision doubly difficult, miners were essentially left to their own devices and could effectively choose how they worked. If there was work discipline in the mines, argues John Williams in his study of south Wales, it was above all self-discipline. ${ }^{122}$

Assistance from fellow workers also facilitated the participation of people with impairments in the working life of collieries. Philip Lloyd, a collier at Waterloo Colliery in Monmouthshire, told the 1842 Children's Employment Commission that one of his daughters 'works in the mine for William Morgan who has lost his leg and cannot do much'. ${ }^{123}$ The presence of kin was particularly important in helping impaired miners remain economically active. In south Wales and Scotland, miners commonly worked in family groups. Even when they did not, many mineworkers across Britain still had family members working close by them at collieries. ${ }^{124}$ Due to the practice of sons following their fathers into the pits, different generations of impaired miners sometimes worked in the same place. Among the victims of an explosion at Gethin Colliery near Merthyr Tydfil in February 1862 were William Lewis, a fortyseven-year-old collier, and his eighteen-year-old son. The elder Lewis had been 'ruptured and confined to his bed' for sixteen weeks before the disaster, while his deceased son had 'lost his leg in the same pit' some time before. Both were 


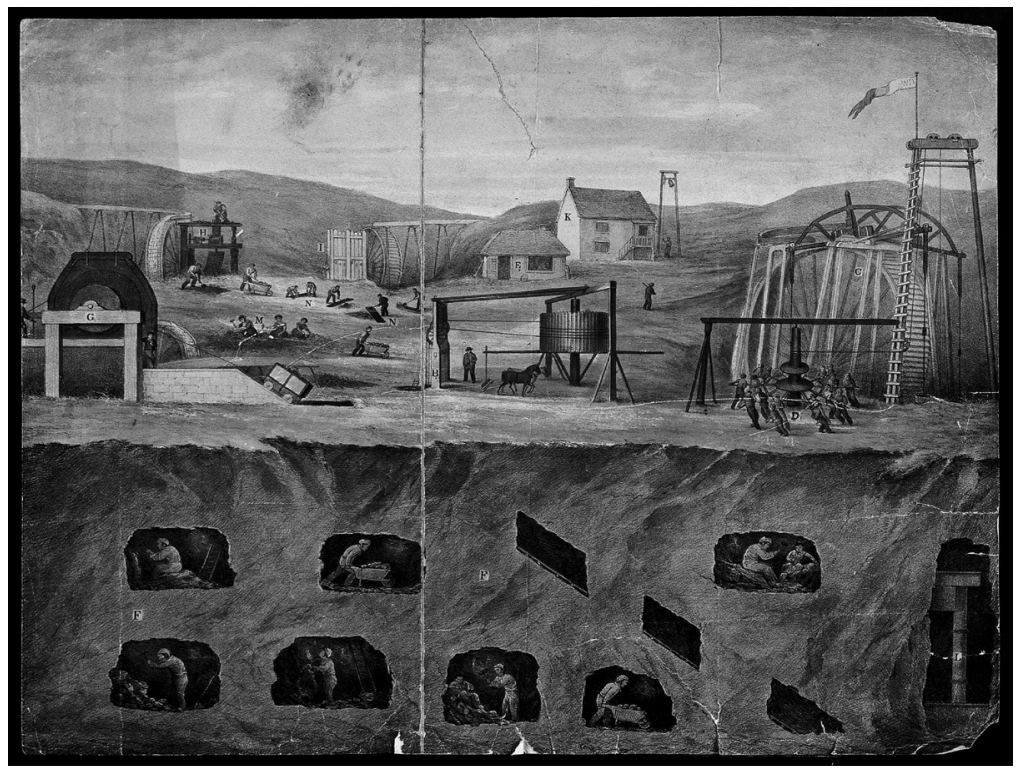

Figure 2 A coal mine: miners at work above and below ground. Wellcome Library, London/CC-BY 4.0.

working underground at the time of the explosion. Newspapers reported that the Lewises had two more sons who had not been involved, including another who had lost a leg in the pit nine months previously, but had been spared from the explosion because he was off work then as the family did not have enough food to pack for his lunch. ${ }^{125}$ There were several other father-and-son teams who worked together in the same mine. ${ }^{126}$ It is not clear whether it was to William Lewis or another man that the Cardiff Times referred on 21 February when it described two unnamed victims of the explosion as a 'poor collier and his son' who worked together because the 'man was delicate in health, and earned but little'. ${ }^{127}$ Three years later, Griffith Ellis, who had a wooden leg, suffocated after another explosion at Gethin Colliery, alongside his brother David. ${ }^{128}$ Tragic as these examples are, they suggest that the help of kin may have enabled impaired miners to carry on working.

Despite the general similarities between coalfields, there were variations that influenced the ease with which people with impairments could take up productive roles in the coal industry. In some places, coal was easier to work. In others, it was far more challenging. These differences help explain the cavilling system in north-east England in which hewers and putters drew lots 
to determine their workplaces underground. The purpose of allocating places in this way was to eliminate accusations of partiality or unfairness. A miner's place, then, was down to chance, not the whim of a mine manager. This was of the utmost importance to Durham and Northumberland pitmen, as a miner's place, or 'cavil', could radically affect his productivity and therefore pay. ${ }^{129}$ For 'crippled' workers, like Edward Rymer, the cavilling system sometimes worked to their advantage by giving them an easy cavil that allowed them to earn a reasonable living despite their diminished physical capacities. At other times, it disadvantaged them. At his second cavilling in Houghton Pit, Rymer drew what he called a "heavy "flat"' and found his strength 'insufficient to bear the task of pushing and lifting iron tubs 12 hours a day'. ${ }^{130}$ When working as a hewer at Old Grange Colliery in partnership with his brother Jack (also described as a 'cripple'), with whom he split shifts, Rymer also found himself 'disabled', in a sense, by the rate of pay. As Rymer himself put it: at Old Grange there were 'good hewers around us, and we were handicapped beyond our strength to get anything like a living at $5 \mathrm{~s}$ a score'. Trying to keep up, his hands became covered with blisters that eventually required medical attention and kept him off work for 'several weeks'. ${ }^{131}$ The cavilling system was unique to north-east England, but the experiences of men like Rymer under it suggest how geological conditions and the allocation of work across the coalfields might influence the ability of impaired or injured miners to participate in coal production in sufficiently profitable ways.

Nineteenth-century colliers proudly proclaimed their 'independence'. However, the flexibility of working arrangements that allowed participation of men with a variety of physical impairments was gradually undermined as the period wore on. ${ }^{132}$ The rise of 'industrial time' and the increasing pace of life brought on by the Industrial Revolution is often regarded as a key factor in the 'disabling' of people with impairments. ${ }^{133}$ As pieceworkers, miners throughout the nineteenth century often worked more to task than time. In the 1840s, Benjamin Martin, a mineral agent for Penydarren Ironworks in south Wales, remarked of colliers there that 'we do not look after their time; they work any number of hours that they like themselves, we pay only for the quantity they send out'. ${ }^{134}$ Under such circumstances, strict industrial timekeeping was clearly not very important, either to miners or managers. Yet changes eroding colliers' ability to determine their own hours of work did occur, albeit slowly and unevenly. In the early phases of industrialisation, mining operations had taken place close to the surface, which made it fairly easy for miners to enter and leave mines as they chose. With the growth of deep-mining, however, colliers became more dependent on winding machinery to access mines and were increasingly tied to particular times for ascending and descending that 
regulated the working day. ${ }^{135}$ The frustration miners felt about the constraints winding equipment placed on their ability to come and go as they pleased is suggested by the tragic fate of Robert Moore. In August 1833, newspapers reported Moore's death after he fell down a 130-yard-deep mineshaft at Dry Clough Colliery in Lancashire, where he was employed. Moore was said to have lost his footing after becoming 'enraged' because he arrived for work 'too late to descend with the coal tub, which had just left the shaft'. ${ }^{136}$ Moore was obviously not a man with complete freedom to decide his own hours of work.

By the time of the 1842 Children's Employment Commission, miners in the west of Scotland were tending to work standardised twelve hour days that began at six o'clock in the morning and were 'anxious to get coal picked out in time to supply the engine' that began its daily task of lifting coal to the surface at six in the evening. ${ }^{137}$ Although miners in different coalfields continued to work varying hours, the growing calls to reduce the working day to eight hours after 1850 may also be seen as a sign that miners, like other industrial workers, were increasingly subjected to time discipline. ${ }^{138}$ The introduction of new forms of work discipline was particularly evident in the new integrated coal and iron companies that came to dominate coal production in the west of Scotland and parts of south Wales between the 1830s and 1870s. Production in these companies was geared to very different rhythms than those of smaller concerns supplying local domestic consumption, and the consistent rather than fluctuating demand for coal put greater pressure on worker productivity. ${ }^{139}$ Taken together, these developments potentially reduced the 'somatic flexibility' available to impaired workers in the industry by undermining their ability to determine their own hours and patterns of work.

Changes in coal-extraction techniques may also have challenged miners' sense of independence and placed greater constraints on older or impaired workers working underground. Although bord-and-pillar mining was never fully displaced during the nineteenth century, from the 1860s 'longwall' mining became more popular, first in Scotland and later in south Wales and north-east England. ${ }^{140}$ Whereas bord-and-pillar extraction favoured hewers working individually, longwall cutting revolved around teams of miners hewing coal from the seam alongside each other in a line. The system had economic advantages, particularly in increasing the volume of marketable coal and reducing waste. ${ }^{141}$ This may have placed those unable to work at the same pace as others at a disadvantage and cast them as a risk to productivity or safety. James Thain, who worked in a team of longwall miners in Pembrokeshire at the end of the nineteenth century, recalled that those men who lagged behind made the working face 'irregular, which often caused the roof to break and the coal to become set or much harder to dig'. This was the cause of many arguments that 
required intervention from the manager or his assistant. Thain remembered hewing alongside an 'old man' who had a 'bad habit of allowing the part of the working face near to me to hang behind'. On at least one occasion, this led to a roof fall that trapped the old man. Luckily for him, the old worker survived the accident but was severely admonished by Thain who told him to take it as a lesson 'and don't let your place hang back again endangering the life of yourself and others'. ${ }^{142}$ Thain's memory of the incident indicates that not all old or impaired mineworkers were always treated with kindness or sympathy by workmates. At times, their diminished capacities could also make them the target of discrimination, prejudice and hostility in the workplace.

The demise of stalls may also have increased managerial pressure on colliers. Although miners with impairments continued to work at collieries employing the longwall method, the greater coordination of workers required by this system meant they were more likely to come under close supervision than in bord-and-pillar mining. Keen to avoid disruptions to production like the one Thain described, it is possible that managers in charge of longwall mines became less tolerant of 'disabled' miners unable to 'keep up' and were less likely to assign them face work. Ultimately, longwall mining would lead to the greater adoption of machine cutting and the mechanisation of coal extraction in the twentieth century, further increasing the pace of mine work. ${ }^{143} \mathrm{We}$ should not, however, exaggerate the impact of these changes. The earning power of older miners remained healthy for most of this period, beginning to fall only in a man's fifties. Furthermore, even if their workmates did not particularly like it, 'old' men like the one encountered by Thain were still working at longwall mining well into the late nineteenth century and beyond. ${ }^{144}$ Nevertheless, as we shall see in Chapter 5, the employment of older miners did become more contested towards the end of the nineteenth century, due to fears that they posed a financial risk to employers because of their perceived greater susceptibility to compensable injury. Changes in coal extraction may have added to these concerns. ${ }^{145}$

\section{Conclusion}

In contrast to the view that industrial expansion rapidly and decisively excluded impaired people from the workforce, evidence from Britain's coal industry in the period 1780-1880 indicates a more complicated picture in which experiences of 'disabled' miners varied considerably. The shift to coalpowered technology fuelled and sustained Britain's economic expansion in this period and contributed to the enormous growth of the coal industry. Yet the development of the coal industry was uneven and had distinctive regional 
characteristics. Systems of labour organisation and methods and conditions of work varied considerably, not only between coalfields, but also between individual collieries in each coalfield. As Thomas Burt's comments that began this chapter suggest, physical impairments were a common sight in Britain's nineteenth-century coal mines, but they were more visible in some mines than others. This reflected not only varying safety standards between collieries, which the system of national inspection brought in after 1850 sought to address, but also the local factors that permitted miners with impairments to re-enter the workforce after injury. In the case of women and young children, it was legislation prompted by moral concerns that played a more decisive role in 'disabling' them from working underground than physical incapacity.

The expansion of the coal industry was widely associated with growing risks to mineworkers, but the exact scale of injury or disablement is difficult to document in an era where reporting of non-fatal accidents was patchy and where there was little consensus on what constituted a 'serious injury'. It is therefore difficult to substantiate the view that industrial expansion produced impairment on a mass scale, although this idea was frequently used to critique industrial practices. There was no simple correlation between 'serious injury' and disability; on the one hand, mine inspector reports often stated that the seriously hurt were returned to 'usefulness', on the other, as we shall see in the following chapter, serious injury was not the only source of impairment for coalminers. Statistics for non-fatal injuries therefore provide limited evidence of the scale or nature of impairments facing mineworkers.

Taken together, the material examined in this chapter cautions against monolithic interpretations of disability and suggests there was no simple correlation between impairment and inability to work. During the so-called 'classical' period of Britain's industrial expansion, from the mid-eighteenth to the mid-nineteenth centuries, people with impairments continued to find work in mining. The survival of 'pre-industrial' working practices, such as the relative independence of hewers, the continuation of work in kin groups, and working to task, may have helped miners with impairments to remain economically active in the industry, retaining some of the 'somatic flexibility' characteristic of earlier periods. ${ }^{146}$ Nevertheless, this may have been undermined over time by economic developments such as the spread of longwall mining and the stricter discipline imposed by mechanisation and the incessant demands of the iron industry in parts of south Wales and west Scotland.

This chapter has indicated the importance of understanding the nature and conditions of work and the culture and structure of the workplace to interpreting experiences of disability and industrialisation. A certain degree of impairment or physical scarring was expected and might mark a man out 
as a 'survivor' and earn him the respect of others. However, Edward Rymer and James Thain's memories of mining show how 'cripple' or elderly miners might face abuse. Their writings also illustrate the ways in which the structure of the workplace, including local customs of labour such as cavilling in north-east England, might variously work to enable injured mineworkers to earn a living or present disabling barriers. The work undertaken by miners with impairments was not always well paid, nor did the 'boys' work' done by some disabled men carry the same prestige as other tasks. Mines offered diverse employment opportunities, but the meanings of work adhered to a strict hierarchy of status, closely related to age. That said, the perception of some disabled people's work as 'lowly' does not mean it did not have value to those who undertook it. For Rymer, work for a 'cripple' such as himself was part of his 'hard fight to live', to support himself and avoid dependency and was a source of pride. ${ }^{147}$ The employment of miners with impairments was consistent with cultural values that demanded that people with disabilities avoid becoming a 'burden' by remaining productive where possible. As we shall see in the following chapter, the whole edifice of medical care in Britain's coalfields was built upon this objective.

\section{Notes}

1 Thomas Burt and Aaron Watson, Thomas Burt, M.P., D.C.L., Pitman and PrivyCouncillor: an Autobiography, with Supplementary Chapters by Aaron Watson (London: Unwin, 1924), 84, 93, 94.

2 Daniel Blackie, 'Disability and Work during the Industrial Revolution in Britain', in Michael Rembis, Catherine Kudlick and Kim E. Nielsen (eds), The Oxford Handbook of Disability History (New York: Oxford University Press, forthcoming).

3 PP 1842 (380), Commission for Inquiring into the Employment and Condition of Children in Mines and Manufactories. First Report of the Commissioners, 24-5.

4 Angela V. John, By the Sweat of Their Brow: Women Workers at Victorian Coal Mines (London: Routledge and Kegan Paul, 1984), 21; J. H. Morris and L. J. Williams, The South Wales Coal Industry 1841-1875 (Cardiff: University of Wales Press, 1958), 214.

5 John, Sweat of Their Brow, 24.

6 Ibid., 24-5.

7 Ibid., 24; Robert Duncan, The Mineworkers (Edinburgh: Birlinn, 2005), 35, 70.

8 Duncan, The Mineworkers, 80-2.

9 John, Sweat of Their Brow, 22; Christopher A. Whatley, 'A Caste Apart? Scottish Colliers, Work, Community and Culture in the Era of "Serfdom”, c. 1606-1799', Journal of the Scottish Labour History Society, 26 (1991), 3-20. 
105 \& 6 Victoria Cap. XCIX An Act to Prohibit the Employment of Women and Girls in Mines and Collieries, to Regulate the Employment of Boys, and to Make other Provisions Relating to Persons Working Therein, 10 August 1842.

11 John, Sweat of Their Brow.

12 Roy Church, The History of the British Coal Industry, vol. 3: 1830-1913: Victorian Pre-Eminence (Oxford: Clarendon Press, 1986), 191.

13 Some children lied about their age to work below ground. For an example, see Edmund Stonelake in A. Mòr O'Brien (ed.), The Autobiography of Edmund Stonelake, (Bridgend: D. Brown and Sons, 1981), 49.

14 PP 1842 (380), 30.

15 'The Collieries - No. 1', Monthly Supplement of the Penny Magazine of the Society for the Diffusion of Useful Knowledge, 28 February-1 March 1835, 123-4.

16 John Benson, British Coalminers in the Nineteenth Century: A Social History (Dublin: Gill and Macmillan, 1980), 28-30.

17 George Parkinson, True Stories of Durham Pit-Life (London: C. H. Kelly, 1912), 1.

18 Alan Campbell and Fred Reid, 'The Independent Collier in Scotland', in Royden Harrison (ed.), Independent Collier: The Coal Miner as Archetypal Proletarian Reconsidered (Hassocks: Harvester Press, 1978), 57; Robert Colls, Pitmen of the Northern Coalfield: Work, Culture and Protest, 1790-1850 (Manchester: Manchester University Press, 1987), 11, 15.

19 Parkinson, True Stories, 1.

20 'On the Habits and Diseases of Northern Pitmen', Colliery Guardian, 12 September 1863, 204.

21 'The Collieries', 127.

22 Herbert Mackworth, 'Mines: Accidents in Them, and Sanitary Condition of Them' in Bristol Mining School, Lectures Delivered at the Bristol Mining School, 1857 (Bristol: Bristol Mining School, 1859), 183.

23 M. W. Flinn, The History of the British Coal Industry, vol. 2: 1700-1830: The Industrial Revolution (Oxford: Clarendon Press, 1984), 87, 91, 106-8.

24 Campbell and Reid, 'Independent Collier in Scotland', 57.

25 Morris and Williams, South Wales Coal Industry, 235.

26 Martin Daunton, 'Down the Pit: Work in the Great Northern and South Wales Coalfields, 1870-1914', Economic History Review, 34:4 (1981), 578-97; Morris and Williams, South Wales Coal Industry, 190-1.

27 Daunton, 'Down the Pit'; Morris and Williams, South Wales Coal Industry, 190-1.

28 Benson, British Coalminers, 54.

29 Anthony Errington, Coals on Rails, Or the Reason of My Wrighting: The Autobiography of Anthony Errington, a Tyneside Colliery Waggon and Waggonway Wright from his Birth in 1778 to around 1825. P. E. H. Hair (ed.) (Liverpool: Liverpool University Press, 1988); Benson, British Coalminers, 29.

30 Cited in Church, British Coal Industry, 195.

31 Burt, Autobiography, 109.

32 Daunton, 'Down the Pit', 590. 
33 Stonelake, Autobiography, 55.

34 Rev. Thomas Gisborne, 'A General View of the Situation of the Mining Poor, Compared with That of Some Other Classes of the Poor' in Society for Bettering the Condition and Increasing the Comforts of the Poor, The Reports of the Society for Bettering the Condition and Increasing the Comforts of the Poor, vol. I (London: W. Bulmer and Co., 1798), 369.

35 Church, British Coal Industry, 571.

36 For example, PP 1842 (380), 157; cf. H. H. B., Black Diamonds; or, the Gospel in a Colliery District (London: James Herbert and Col, 1861), 123-4.

37 Steve Sturdy, 'The Industrial Body' in Roger Cooter and John Pickstone (eds), Companion to Medicine in the Twentieth Century (London: Routledge, 2003), 218.

38 Jamie L. Bronstein, Caught in the Machinery: Workplace Accidents and Injured Workers in Nineteenth-Century Britain (Stanford, CA: Stanford University Press, 2008), 158.

39 Benson, British Coalminers, 64; Colls, Pitmen, 53.

40 Benson, British Coalminers, 76-9.

41 Church, British Coal Industry, 576.

42 'The Collieries', 125; PP 1842 (380), 40; Huw Beynon and Terry Austrin, Masters and Servants: Class and Patronage in the Making of a Labour Organisation; the Durham Miners and the English Political Tradition (London: Rivers Oram, 1994), 29-46; Colls, Pitmen, 45-73; Bronstein, Caught in the Machinery, 120, 137.

43 United Association of Colliers, A Voice from the Coalmines, Or, A Plain Statement of the Various Grievances of the Pitmen of the Tyne and Wear: Addressed to the Coal Owners, their Head Agents, and a Sympathizing Public (South Shields: J. Clark, $1825), 25$.

44 PP 1842 (380), 40; Morris and Williams, South Wales Coal Industry, 234.

45 John. A. Hassan, 'The Landed Estate, Paternalism and the Coal Industry in Midlothian, 1800-1880', The Scottish Historical Review, 59 (1980), 77. Despite Hassan's claim, bonds of five years were probably quite exceptional in nineteenthcentury Scotland. In 1842, the Commission on Children's Employment reported that colliers in east Scotland were commonly hired on two-week contracts. PP 1842 (380), 40. Whatley, 'A Caste Apart?'

46 Bronstein, Caught in the Machinery, 11.

47 Observations here are based on table 4 in Benson, British Coalminers, 219; Duncan, The Mineworkers, 119.

48 P. E. H. Hair, 'Mortality from Violence in British Coal Mines, 1800-1850', Economic History Review, 21:3 (1968), 559.

49 Mills, Regulating Health and Safety, 80-4 and ch. 4 passim.

50 John Benson, 'Non-Fatal Coalmining Accidents', Bulletin of the Society for the Study of Labour History, 32 (1976), 20-2.

51 P. W. J. Bartrip and S. B. Burman, The Wounded Soldiers of Industry: Industrial Compensation Policy 1833-1897 (Oxford: Clarendon Press, 1983), 21-2.

52 PP 1842 (380), 152. 
53 PP 1842 (381), Children's Employment Commission. Appendix to the First Report of the Commissioners. Mines. Part 1. Reports and Evidence from Sub-Commissioners, 140.

54 PP 1842 (382), Children's Employment Commission. Appendix to First Report of Commissioners. Mines. Part 2. 553.

55 PP 1842 (381), 550.

56 Mills, Regulating Health and Safety, 19.

57 Ibid., 80-4; 18 \& 19 Victoria Cap. CVIII, An Act to Amend the Law for the Inspection of Coal Mines in Great Britain, 14 August 1855.

5835 \& 36 Victoria Cap. LXXVI, An Act to Consolidate and Amend the Acts Relating to the Regulation of Coal Mines and Certain Other Mines, 10 August 1872. The question of compensation is explored more fully in Chapter 5. See also, Sturdy, 'Industrial Body', 220-1.

59 PP 1864 [3352] Mines. Reports of the Inspectors of Mines, to Her Majesty's Secretary of State, for the Year 1863, 62.

60 Ibid., 166.

61 PP 1875 [C.1216], Mines. Reports of the Inspectors of Mines, to Her Majesty's Secretary of State, for the Year 1874, 113.

62 Bartrip and Burman, Wounded Soldiers of Industry, 8-13.

63 Flinn, British Coal Industry, 412; cf. Mills, Regulating Health and Safety, 13.

64 Whitehall Evening Post, 14-17 June 1788.

65 Tyne and Wear Archives, S.PAM/1/6, Printed Address Urging the Formation of a Society for the Prevention of Accidents in Coal Mines, 1 September 1813.

66 PP 1830 (9), Report from the Select Committee of the House of Lords Appointed to Take into Consideration the State of the Coal Trade in the United Kingdom; with the Minutes of Evidence Taken Before the Committee, and an Appendix and Index, 31.

67 Church, British Coal Industry, 322; Colls, Pitmen, 20-3.

68 Church, British Coal Industry, ch. 4 outlines these innovations in detail.

69 Ibid., 322-3.

70 Hair, 'Mortality from Violence', 545; Burt, Autobiography, 22.

71 Benson, British Coalminers, 41; Hair, 'Mortality from Violence', 557.

72 As Rose notes, historians of other countries or industries have also noted the negative impact of new technologies on the health and safety of industrial workers. Sarah F. Rose, “'Crippled” Hands: Disability in Labor and WorkingClass History', Labor, 2:1 (2005), 35.

73 Stephen Hughes, Collieries of Wales: Engineering and Architecture (Aberystwyth: Royal Commission on the Ancient \& Historical Monuments of Wales, 1994), 65-8; Flinn, British Coal Industry, 110-28.

74 Public Advertiser, 13 June 1787.

75 United Association of Colliers, Voice from the Coal Mines, 9, 12, 16; Mills, Regulating Health and Safety, 18.

76 PP 1830 (9), 32.

77 Colls, Pitmen, 15. 
78 PP 1864 [3352], 158; Bronstein, Caught in the Machinery, 114.

79 'A Coal Miners Evidence', Household Words, 2:37 (1850), 245, 247.

80 Bronstein, Caught in the Machinery, 14.

81 Ibid., 11-12. For earlier examples see Statistical Compendium, table 2.5. Accidents and Injuries to Men and Boys Employed Underground in the Colliery of East Holywell, During the Year Ending May 24th 1841, provided by William Morrison, 'Medical Gentleman', to the 1842 Children's Employment Commission, http:// doi.org/10.5281/zenodo.183686, accessed 24 March 2017.

82 PP 1864 [3352], 120.

83 PP 1870 [C.124], Mines. Reports of the Inspectors of Mines, to Her Majesty's Secretary of State, for the Year 1869, 84.

84 Ibid., 129.

85 Ibid., 142.

86 Bronstein, Caught in the Machinery, 13-14.

87 PP 1856 [2132], Coal mines. Reports of the Inspectors of Coal Mines, to Her Majesty's Secretary of State, 116; PP 1864 [3352], 120.

88 PP 1864 [3252], Mines. Reports of the Inspectors of Mines, to Her Majesty's Secretary of State, for the Year 1862, 55.

89 PP 1881 [C.2903], Mines. Reports of the Inspectors of Mines, to Her Majesty's Secretary of State, for the Year 1880, 196.

90 David M. Turner, Disability in Eighteenth-Century England: Imagining Physical Impairment (New York and London: Routledge, 2012), 127-30. On welfare, see ch. 3.

91 Blackie, 'Disability and Work'.

92 PP 1842 (008), Sanitary Inquiry - Scotland, Reports on the Sanitary Condition of the Labouring Population of Scotland, in Consequence of an Inquiry Directed to be Made by the Poor Law Commissioners, 123. Our emphasis.

93 Martha Stoddard Holmes, 'Working (with) the Rhetoric of Affliction: Autobiographical Narratives of Victorians with Physical Disabilities', in James C. Wilson and Cynthia Lewiecki-Wilson (eds), Embodied Rhetorics: Disability in Language and Culture (Carbondale and Edwardsville: Southern Illinois Press, 2001), 27.

94 PP 1842 (381), 470, 478, 577. For other examples, see Bronstein, Caught in the Machinery, 56.

95 Peter Kirby, Child Workers and Industrial Health in Britain, 1780-1850 (Woodbridge: Boydell Press, 2013), 70-3.

96 James C. Riley, Sick, Not Dead: the Health of British Workingmen during the Mortality Decline (Baltimore, MD and London: Johns Hopkins University Press, 1997), 135.

97 Edward Rymer, The Martyrdom of the Mine, or a Sixty Years Struggle for Life (Middlesbrough, 1898), 2, 3, 5-7.

98 PP 1830 (9), 33.

99 PP 1842 (381), 631. 
100 Benson, British Coalminers, 114; 'On the Habits and Diseases of Northern Pitmen,' Colliery Guardian and Journal of the Coal and Iron Trades, September 12, 1863, 204; Rymer, 'Martyrdom of the Mine', 4.

101 For example, see 'The Great Explosion at the Gethin Colliery. The Coroner's Inquest' (cutting from Merthyr Telegraph, Saturday, January 13, 1866) in TNA, HO 45/7729, Home Office: Registered Papers.

102 As Sarah Rose recognises when she cites the work of Alan Derickson, this also appears to have been the case at many American coal mines in the late-nineteenth and twentieth centuries. Rose, “'Crippled” Hands', 52.

103 Rymer, Martyrdom of the Mine, 8.

104 Edward Slavishak, Bodies of Work: Civic Display and Labor in Industrial Pittsburgh (Durham, NC and London: Duke University Press, 2008), 162.

105 Alan B. Campbell, The Lanarkshire Miners: A Social History of their Unions, 17751974 (Edinburgh: John Donald, 1979), 39.

106 PP 1842 (381), 595, 645.

107 J. T. Arlidge, The Hygiene, Diseases and Mortality of Occupations (London: Percival and Co. 1892), 16.

108 Blackie, 'Disability and Work'.

109 'Explosion in a Coal-Pit, and Melancholy Loss of Life', The Monmouthshire Merlin, 14 August 1841.

110 PP 1842 (381), 128.

111 'The Great Explosion at the Gethin Colliery', Merthyr Telegraph, 13 January 1866.

112 Jules Ginswick (ed.), Labour and the Poor in England and Wales, 1849-1851: the Letters to the Morning Chronicle from the Correspondents in the Manufacturing and Mining Districts, the Towns of Liverpool and Birmingham, and the Rural Districts, 8 Vols (London: Frank Cass, 1983), ii, 63.

113 For other examples, see Hansard, HC Deb 10 March 1846, vol. 84, cols 847-8. See also Merthyr Telegraph, Saturday 29 May 1858.

114 J. R. Leifchild, Our Coal and Our Coal-Pits (London: Longman, Brown, Green, Longmans, 1855), 208, 214.

115 There is also evidence that disabled people in coalfield communities such as Shields on Tyneside may have made a living as water fountain attendants. See PP 1842 (007), Sanitary Inquiry - England. Local Reports on the Sanitary Condition of the Labouring Population of England, in Consequence of an Inquiry Directed to be Made by the Poor Law Commissioners, 443 (Greenhow's evidence).

116 Brendan Gleeson, Geographies of Disability (London: Routledge, 1999), 87.

117 Michael Oliver and Colin Barnes, The New Politics of Disablement (Basingstoke: Palgrave Macmillan, 2012), 61.

118 John Williams, Was Wales Industrialised? Essays in Modern Welsh History (Llandysul, Dyfed: Gomer Press, 1995), 27.

119 Benson, British Coalminers, 55-7; Campbell, Lanarkshire Miners, 35, 109.

120 Parkinson, True Stories, 35.

121 Flinn, British Coal Industry, 82-7, 90-9. 
122 Daunton, 'Down the Pit', 583; Williams, Was Wales Industrialised?, 31; Colls, Pitmen, 29; Campbell, Lanarkshire Miners, 35.

123 PP 1842 (382), 536.

124 For examples, see Burt, Autobiography, 111; Parkinson, True Stories, 18-20.

125 Cardiff Times, 28 February 1862.

126 As indicated by the list of dead: see, Monmouthshire Merlin, 22 February 1862.

127 Cardiff Times, 21 February 1862.

128 Merthyr Telegraph and General Advertiser for the Iron Districts of South Wales, 23 December 1865.

129 Church, British Coal Industry, 275.

130 Rymer, Martyrdom of the Mine, 6.

131 Ibid.

132 Colls, Pitmen, 25-30; Campbell, Lanarkshire Miners, 26-45.

133 Gleeson, Geographies of Disability, 106-7; E. P. Thompson, 'Time, WorkDiscipline and Industrial Capitalism', Past and Present, 38 (1967), 56-97.

134 PP 1842 (382), 653.

135 Morris and Williams, South Wales Coal Industry, 231-2.

136 The Examiner, 18 August 1833. The same report also appeared in The Bristol Mercury, 24 August 1833.

137 PP 1842 (380), 111.

138 Church, British Coal Industry, 238, 251.

139 Campbell and Reid, 'The Independent Collier in Scotland', 69.

140 Daunton, 'Down the Pit'; Morris and Williams, South Wales Coal Industry, 57-62; Flinn, British Coal Industry, 82-91; Duncan, The Mineworkers, 72-7.

141 Church, British Coal Industry, 329-36; Martin Daunton, 'Down the Pit: Work in the Great Northern and South Wales Coalfields, 1870-1914', Economic History Review, 34:4 (1981), 582.

142 James Thain, 'The Memoirs of James Thain of Stepaside, Kilgetty (born 3 May 1870)' in M. R. Connop-Price, Pembrokeshire: the Forgotten Coalfield (Ashbourne: Landmark Publishing, 2004), 224.

143 Daunton, 'Down the Pit', 583-4.

144 David Tonks, 'A Kind of Life Insurance: the Coal-Miners of North-East England 1860-1920', Family and Community History, 2:1 (1999), 45-58, especially 49.

145 Ben Curtis and Steven Thompson, “'This is the country of premature old men:” Ageing and Aged Miners in the South Wales Coalfield, c. 1880-1947', Cultural and Social History, 12:4 (2015), 587-606.

146 Colls, Pitmen, 29-32.

147 Rymer, Martyrdom of the Mine, 6. 